\title{
高土石坝复合加筋抗震措施大型振动台模型试验 与数值模拟
}

杨星 ${ }^{1}$, 余挺 ${ }^{1}$, 陈鹏 $^{2}$, 袁正鍂 $^{3^{*}}$

1. 中国电建集团成都勘测设计研究院有限公司, 成都 610072 ;

2. 东原房地产开发集团有限公司, 上海 201100;

3. 香港科技大学土木及环境工程学系, 香港 999077

*E-mail: zyuanal@connect.ust.hk

收稿日期: 2021-08-13; 接受日期: 2021-11-26; 网络版发表日期: 2022-08-10 国家重点研发计划(编号: 2016YFC0401907)资助项目

摘要 针对我国西部强震区水电工程建设中高土石坝抗震安全这一突出问题, 提出了一种高土石坝复合加筋抗 震措施, 通过未加筋模型坝和复合加筋模型坝大型振动台对比试验, 验证了复合加筋抗震措施的有效性和可靠 性, 并结合数值模拟探讨了复合加筋抗震措施的加固机制. 研究结果表明: 相比于未加筋模型坝, 复合加筋抗震 措施对坝顶加速度响应具有一定的抑制作用, 能够有效抑制坝顶堆石松动和滑移, 减小坝体地震永久变形. 数值 模拟分析进一步表明, 坝顶复合加筋区域剪应变幅值和分布规律发生了明显的改变, 较大的剪应变形成在坝内筋 材前端, 即潜在滑动面由未加筋的浅层滑动转变为深层滑动, 因此, 高土石坝复合加筋抗震措施提高了大坝的抗 震安全性. 研究成果可为强震区高土石坝的抗震设计提供借鉴.

关键词高土石坝, 复合加筋, 抗震措施, 振动台模型试验, 数值模拟, 加固机制

\section{1 引言}

水能是一种清洁的可再生能源. 随着对能源需求 的增加和国家将碳达峰、碳中和纳入生态文明建设的 整体布局下，在我国水能资源分布丰富的西部地区正 建或拟建一批大库高坝，以开发利用这些水能资源. 土石坝由于可以就地取材、施工方便、造价较低，并 具有良好的地基适应性和抗震性等优点，是高坝建设 的主要坝型之一, 尤其是在复杂地形、地质(深厚覆盖 层)条件下, 土石坝往往是唯一可供选择的坝型. 目前,
我国西部在建和拟建的土石坝有多座属于 $300 \mathrm{~m}$ 级超 高土石坝，如两河口、双江口、如美、古水和其宗等， 这些高土石坝在国内外鲜有先例, 工程建设难度大.

西部地区同时又是我国地震的强震区，发震频率 和地震强度都非常高. 近年来, 7.0 级以上的强震就发 生了多次，其中最为典型的是2008年5月12日8.0级四 川汶川地震、2010年4月14日7.1级青海玉树地震、 2013年4月20日7.0级四川芦山地震、2017年8月8日7.0 级四川九寨沟地震、2021年5月22日7.4级青海玛多地 震，这些大地震都具有震源深度浅、释放地震能量大

引用格式: 杨星, 余挺, 陈鹏, 等. 高土石坝复合加筋抗震措施大型振动台模型试验与数值模拟. 中国科学: 技术科学, 2022, 52: 1839-1848 Yang X, Yu T, Chen P, et al. Large-scale shaking table model tests and numerical simulation for composite reinforcement aseismic measure of high earth rockfill dam (in Chinese). Sci Sin Tech, 2022, 52: 1839-1848, doi: 10.1360/SST-2021-0369 
的特点, 强震区灾害之惨重令人触目惊心. 位于西部强 震区高土石坝的抗震安全是工程建设最突出的问题之 一, 备受全社会关注. 因此, 开展高土石坝抗震措施研 究是一个具有实际工程意义并非常紧迫的重要课 题 ${ }^{[1 \sim 3]}$.

韩国城和孔宪京 ${ }^{[4]}$ 曾建议了减缓坝坡、适当放宽 坝顶宽度和加大坝顶区填筑料粒径或采用抗剪强度较 高的土料的土石坝综合抗震措施，后又提出了钉结护 面板的坝顶抗震措施. 曹学兴等人 ${ }^{[5]}$ 提出了利用Hardfill材料对高土石坝进行加固的抗震措施. 刘平等人 ${ }^{[6]}$ 提出了一种高聚物胶凝材料加固高土石坝坝顶区堆石 的抗震措施. 针对目前国内外缺少 $300 \mathrm{~m}$ 级超高土石坝 抗震设计经验, 在总结以往高土石坝抗震措施优缺点 的基础上，杨星等人 ${ }^{[7,8]}$ 提出了一种高土石坝复合加筋 抗震措施. 本文针对此高土石坝复合加筋抗震措施, 通 过未加筋模型坝和复合加筋模型坝大型振动台对比试 验, 验证复合加筋抗震措施的有效性和可靠性, 并结合 数值模拟探讨复合加筋抗震措施的加固机制, 以期为 我国西部强震区正建和拟建的高土石坝的抗震设计提 供借鉴和参考.

\section{2 高土石坝复合加筋抗震措施}

已有研究表明, 坝顶是高土石抗震设计的关键部 位. 高土石坝遭遇地震发生破坏时，破坏将首先从坝 顶部开始，破坏模式主要表现为坝顶部堆石松动、滚 落、坍塌，甚至出现局部浅层滑动，并且破坏是一个 “由表及里”、由浅入深、逐步发展的过程 ${ }^{[9,10]}$. 在 2008年“5·12”汶川大地震中, 坝高 $156 \mathrm{~m}$ 的紫坪铺面板 堆石坝就出现了坝顶震陷、坝顶部下游坝坡干砌石松 动和滑移、坝顶结构损坏、面板挤压破坏和施工缝错 台等震害, 对大坝安全造成严重影响 ${ }^{[11,12]}$.

在强震区修建的高土石坝一般都采取了在坝顶部 设置加筋结构, 以增强大坝的抗震安全性, 其中, 土工
格栅和钢筋两种抗震加筋材料在高土石坝工程实践中 均有应用, 如坝高 $124.5 \mathrm{~m}$ 的冶勒沥青混凝土心墙堆石 坝和坝高 $240 \mathrm{~m}$ 的长河坝砾石土心墙堆石坝在坝顶部 采取了铺设土工格棶的抗震措施, 坝高 $261.5 \mathrm{~m}$ 的糯扎 渡砾石土心墙堆石坝在坝顶部采取了铺设钢筋的抗震 措施 ${ }^{[13,14]}$. 鉴于 $300 \mathrm{~m}$ 级超高土石坝的复杂性和抗震安 全的重要性，在同时吸收柔性加筋材料(土工格栅)和 刚性加筋材料(钢筋)在高土石坝抗震加固方面优点的 基础上, 杨星等人 ${ }^{[7,8]}$ 开发了一种高土石坝复合加筋抗震 措施，并获得国家发明专利授权(ZL 201110122191.5). 高土石坝复合加筋抗震措施位置示意图及主要构成如 图1所示(图中 $H$ 为坝高).

\section{3 大型振动台对比模型试验}

大型振动台对比模型试验在南京工业大学大型高 性能地震模拟振动台上进行, 其台面尺寸为 $3.36 \mathrm{~m} \times$ $4.86 \mathrm{~m}$, 水平最大加速度 $\pm 1.0 \mathrm{~g}$, 水平最大位移 $\pm 120 \mathrm{~mm}$, 最大载重 $15 \mathrm{t}$, 工作频率 $0.1 \sim 50 \mathrm{~Hz}$. 试验数据采用 98 通 道动态信号采集系统, 自动采集、记录和存储传感器 的响应数据 ${ }^{[15]}$.

\section{1 模型试验设计}

模型坝坝高 $100 \mathrm{~cm}$, 坝顶宽 $10 \mathrm{~cm}$ ，上下游坡比均 为 $1: 1.7$, 筑坝料最大粒径 $20 \mathrm{~mm}$, 级配依据某典型高土 石坝的堆石料级配进行选配, 模型和原型的级配曲线 如图2所示. 试验控制填筑密度为 $1.9 \mathrm{~g} / \mathrm{cm}^{3}$, 并在模型 坝上游采用复合土工膜蓄水来模拟库水作用, 蓄水高 程为 $80 \mathrm{~cm}$. 模型坝主要监测仪器布置情况如图 3 所示.

相似关系根据弹性-重力相似理论确定 ${ }^{[16]}$, 其中, 时间比尺 $\lambda_{t}=10$, 密度比尺 $\lambda_{\rho}=1.15$, 加速度比尺 $\lambda_{a}=1.0$. 分别采用镀锌铁丝和经编聚酯纤维(PET) 来模拟坝内 实际的钢筋和土工格栅，用镀锌铁皮网来模拟坝面扁 钢网 ${ }^{[17,18]}$. 在坝顶部 $20 \mathrm{~cm}$ 范围内的堆石料中, 共布置 5

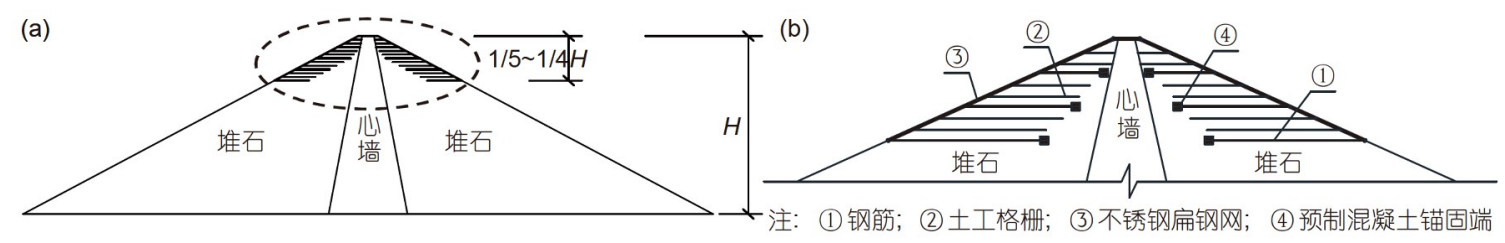

图 1 高土石坝复合加筋抗震措施. (a) 位置示意图; (b) 结构放大图

Figure 1 Composite reinforcement aseismic measure of a high earth rockfill dam. (a) Location drawing; (b) amplified drawing. 


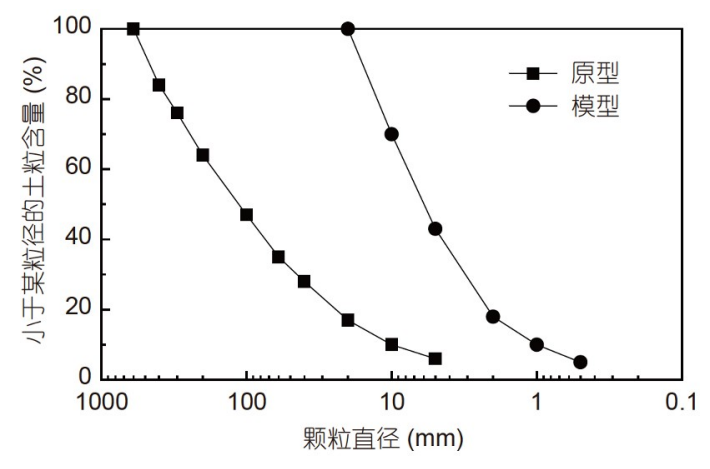

图 2 筑坝堆石料级配曲线

Figure 2 Particle size distribution of the rockfill materials.

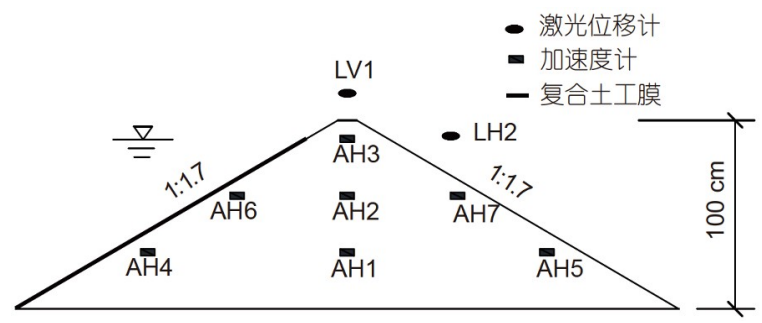

图 3 模型坝主要监测仪器布置图

Figure 3 Layout drawing of the main monitoring equipment of the dam.

层镀锌铁丝和经编聚酯纤维, 由下向上交替布置, 层距 为 $4 \mathrm{~cm}$. 由下向上第一层、第二层和第三层镀锌铁丝 的长度分别为 20,20 和 $7 \mathrm{~cm}$, 每一层镀锌铁丝的水平 向间距为 $5 \mathrm{~cm}$, 镀锌铁丝与坝面铁皮网焊接. 第一层 和第二层经编聚酯纤维的长度分别为 20 和 $14 \mathrm{~cm}$. 坝 顶的镀锌铁丝对穿上下游，将坝面铁皮网相连. 镀锌 铁丝直径为 $2 \mathrm{~mm}$, 铁皮网的厚度为 $1 \mathrm{~mm}$, 弹性模量为 $200 \mathrm{GPa}$, 泊松比为 0.3 . 经编聚酯纤维的力学性能参数:
屈服强度为 $6.5 \mathrm{MPa}$, 断裂伸长率为 $15 \%$ $25 \%$, 密度为 $1.3 \sim 1.38 \mathrm{~g} / \mathrm{cm}^{3}$, 弹性模量为 $45 \mathrm{MPa}$. 为保证模型坝的 填筑密度, 在叠层剪切模型箱内采取分层填筑, 每层筑 坝料填筑高度为 $10 \mathrm{~cm}$, 经人工振捣使其达到设计密 度, 填筑完成后的模型坝如图4所示.

\section{2 输入地震动及试验加载工况}

地震动特性一般包括地震动强度、频谱特性和持 时三个方面 ${ }^{[19]}$. 试验选取两条具有代表性的地震波, 分别是 1952年美国加利福尼亚大地震中的Taft波和 2008年四川汶川大地震中的松潘波. 根据时间相似关 系压缩后的加速度时程曲线及傅里叶谱分别如图 5 和 6 所示, 本文试验的加载工况见表1.
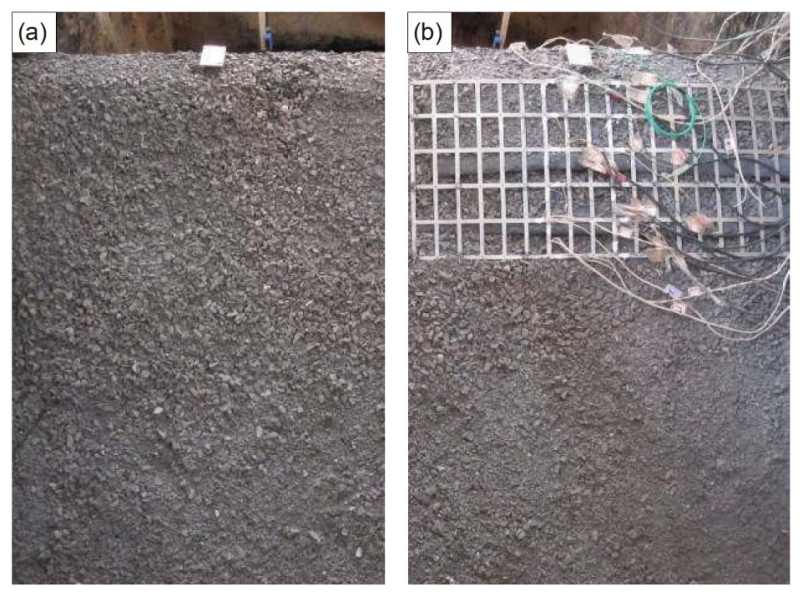

图 4 (网络版彩图)填筑完成后的模型坝. (a) 未加筋; (b) 复 合加筋

Figure 4 (Color online) The dam after construction. (a) Without reinforcement; (b) with composite reinforcement.
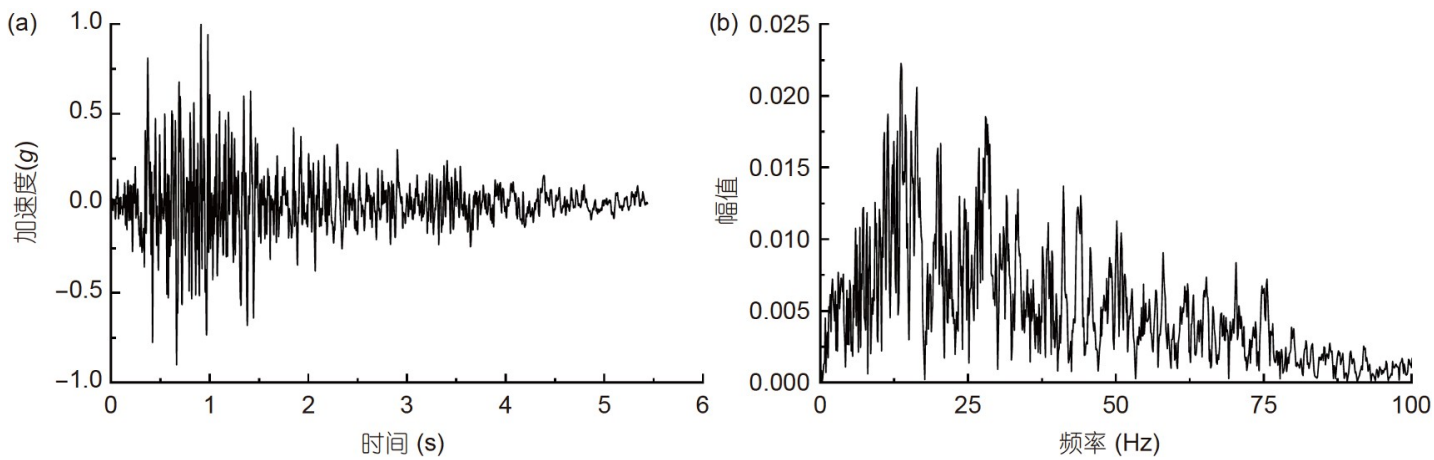

图 5 输入的Taft波及傅里叶谱. (a) 加速度时程曲线; (b) 傅里叶谱

Figure 5 The input Taft wave and Fourier spectrum. (a) Acceleration time history; (b) Fourier spectrum. 


\section{4 结果与分析}

\section{1 加速度响应}

地震过程中加速度所产生的地震惯性力是引起坝 体破坏的重要原因，坝体加速度响应及其分布规律是

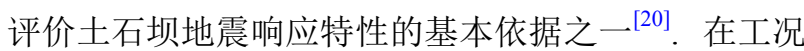
1作用下，未加筋模型坝和复合加筋模型坝坝顶测点 $\mathrm{AH} 3$ 监测的水平向加速度时程曲线如图7所示.

图8为加速度放大系数沿坝高的分布图. 由图 8 可
知，加速度响应沿坝高均存在放大效应，但复合加筋 模型坝坝顶加速度放大系数小于未加筋模型坝，这与 王年香等人 ${ }^{[21]}$ 开展的土工格栅加固长河坝坝顶离心 机振动台模型试验得出的结论一致. Kim等人 ${ }^{[22]}$ 利用 离心机开展的土心墙堆石坝和混凝土面板堆石坝地震 响应模型试验表明，加速度放大系数会随坝顶堆石松 动而显著增大. 杨正权等人 ${ }^{[23]}$ 开展的紫坪铺面板堆石 坝坝坡震后抗震加固大型振动台模型试验发现，浆砌 石护坡由于具有良好的整体性，坝体加速度放大系数
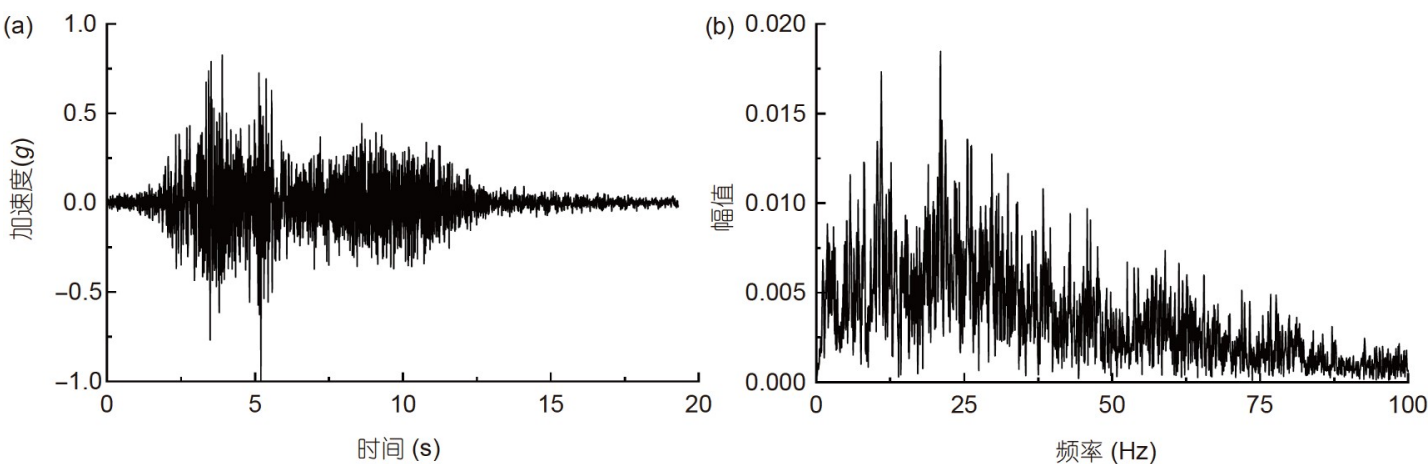

图 6 输入的松潘波及傅里叶谱. (a) 加速度时程曲线; (b) 傅里叶谱

Figure 6 The input Songpan wave and Fourier spectrum. (a) Acceleration time history; (b) Fourier spectrum.

表 1 振动台模型试验加载工况

Table 1 Loading conditions of the shaking table tests

\begin{tabular}{ccccccc}
\hline 工况序号 & 输入地震波 & 工况代号 & 输入PGA $(g)$ & 持时 $(\mathrm{s})$ & 备注 \\
\hline 1 & Taft波 & TA-1 & 0.3 & 5.4 & 20 & 蓄水 \\
2 & 松潘波 & SP-1 & 0.3 & 20 & 蓄水 \\
3 & 松潘波 & SP-2 & 0.5 & 蓄水 \\
\hline
\end{tabular}
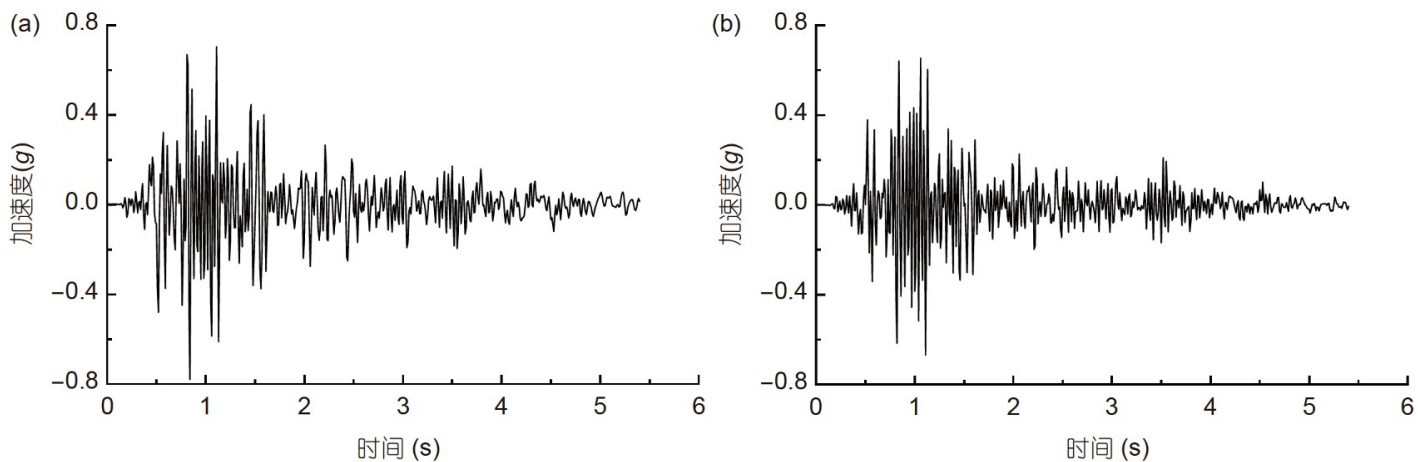

图 7 坝顶水平向加速度时程曲线(工况1). (a) 未加筋; (b) 复合加筋

Figure 7 Horizontal acceleration time history of the dam crest (under the first condition). (a) Without reinforcement; (b) with composite reinforcement. 


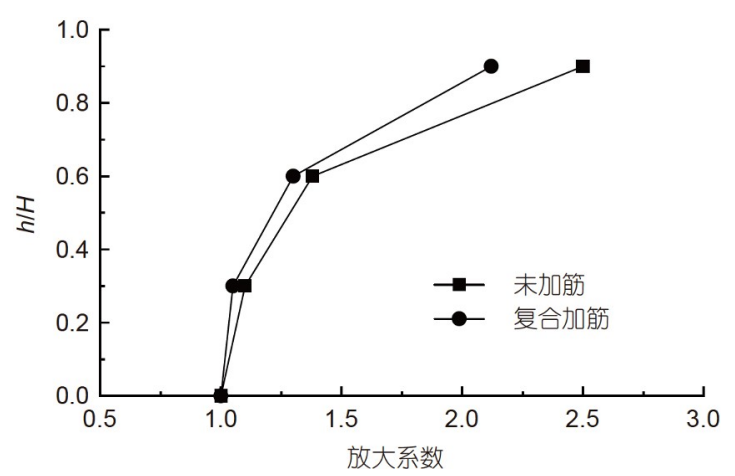

图 8 加速度放大系数沿坝高分布(工况 1$)$

Figure 8 The distribution of the acceleration amplified coefficient along the dam height (under the first condition).

小于干砌石护坡．复合加筋抗震措施能够有效地抑制 坝顶堆石松动(见后文详述), 从而对坝顶加速度响应 具有一定的抑制作用.

\section{2 频谱分析}

工况3作用下未加筋模型坝和复合加筋模型坝坝 顶测点AH3监测的加速度时程进行傅里叶变换(FFT), 得到的傅里叶谱如图9所示. 由图9可知, 输入地震波经 模型坝堆石介质传播后，其频谱特性发生了明显改变: 一方面, 由于堆石料材料阻尼的作用, 吸收了一部分地 震波能量, 对地震波高频部分具有滤波作用; 另一方 面，对某些频段的能量加以放大，与模型坝自振频率 接近的频段, 傅里叶谱的幅值较其他频段显著增大. 对比图9(a)和(b)可以看出, 复合加筋模型坝的坝顶加 速度傅里叶谱的幅值较未加筋小, 说明复合加筋抗震 措施具有减小地震波能量的抗震效果.

\section{3 地震永久变形与破坏形态}

地震引起的不均匀沉降会造成坝体出现裂缝, 过 大的地震沉降会使坝体存在库水漫顶的风险. 坝顶震 陷直接反映了土石坝地震永久变形的程度, 可为合理 设计坝顶超高和评判大坝抗震安全提供依据 ${ }^{[24]}$.

图10为工况3作用下, 未加筋模型坝和复合加筋模 型坝激光位移计 LV 1 监测的坝顶坚向位移时程曲线. 由图 10 可见, 在较强振动作用下 $(0.5 \mathrm{~g})$, 复合加筋模型 坝的坝顶坚向永久变形明显小于未加筋模型坝，说明 复合加筋抗震措施能有效减小坝体地震沉降. 此外, 尽管最终的变形趋势都是产生不可恢复的坚向地震永
久变形，但未加筋模型坝的坚向位移时程曲线出现了 较大的波动, 复合加筋模型坝的坚向位移时程曲线则 较为平缓, 这主要是因为未加筋模型坝坝顶堆石在振 动过程中出现了松动和隆起造成的, 复合加筋模型坝 坝顶堆石整体性保持较好, 从而进一步说明了复合加 筋抗震措施的抗震效果. 同时还可以看出, 未加筋模
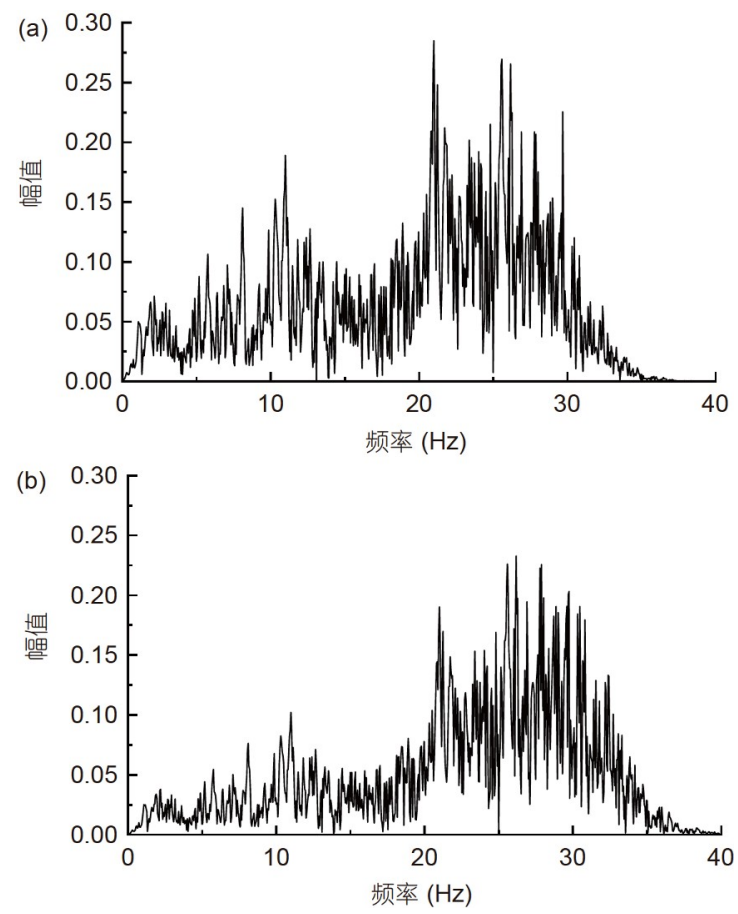

图 9 坝顶加速度傅里叶谱(工况3). (a) 未加筋; (b) 复合加 筋

Figure 9 Acceleration Fourier spectrum of the dam crest (under the third condition). (a) Without reinforcement; (b) with composite reinforcement.

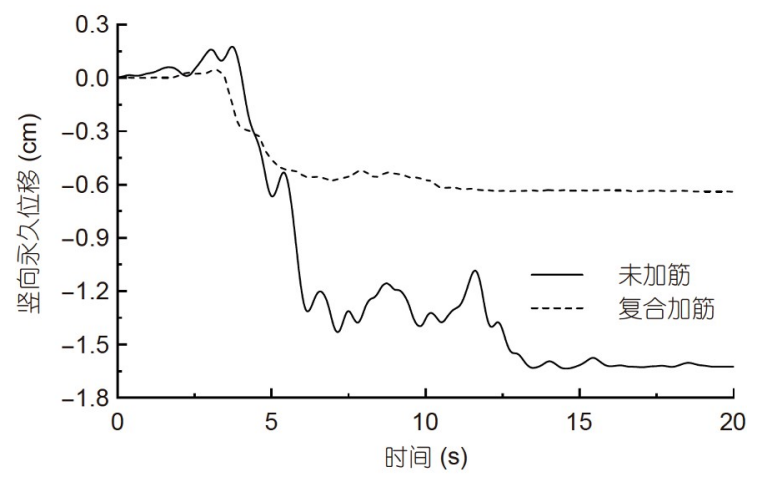

图 10 坝顶坚向位移时程曲线(工况3)

Figure 10 Vertical displacement time history of the dam crest (under the third condition). 
型坝和复合加筋模型坝，在输入加速度幅值较大的第 3 12 s时间段(图6(a))坚向位移均迅速增加，之后随着 地震波能量的衰减, 变形趋于稳定.

工况3作用结束后, 未加筋模型坝和复合加筋模型 坝的破坏形态如图11所示. 由图11(a)可以看出, 未加筋 模型坝坝顶部出现了较严重的破坏. 在模型试验振动 过程中观察到，坝顶部堆石首先出现松动、滚落，逐 步剥离, 破坏是一个渐进的过程, 随着振动的持续和 增强，最后发展成较大范围的滑动，坝顶宽度也被一 定程度地削减，标识点随着坝坡堆石滑动出现了明显 的滑移. 复合加筋模型坝没有出现明显的破坏现象, 坝顶宽度和标识点的位置较试验前基本无变化，但在 复合加筋与未加筋的坝坡过渡处, 出现了少许堆石松 动、滚落, 甚至脱空现象, 如图11(b)所示. 对比图11(a) 和(b)可以得出, 针对未加筋模型坝出现的坝顶堆石松 动、滚落和浅层滑动等破坏，复合加筋抗震措施起到 了有效的抑制作用，具有针对性的抗震效果，但应做 好复合加筋与未加筋在坝坡过渡处的衔接.

\section{5 振动台试验数值模拟}

数值计算采用 $F L A C^{3 \mathrm{D}}$ 动力有限差分程序, 该程序 采用完全非线性分析方法，通过选择合适的阻尼形式
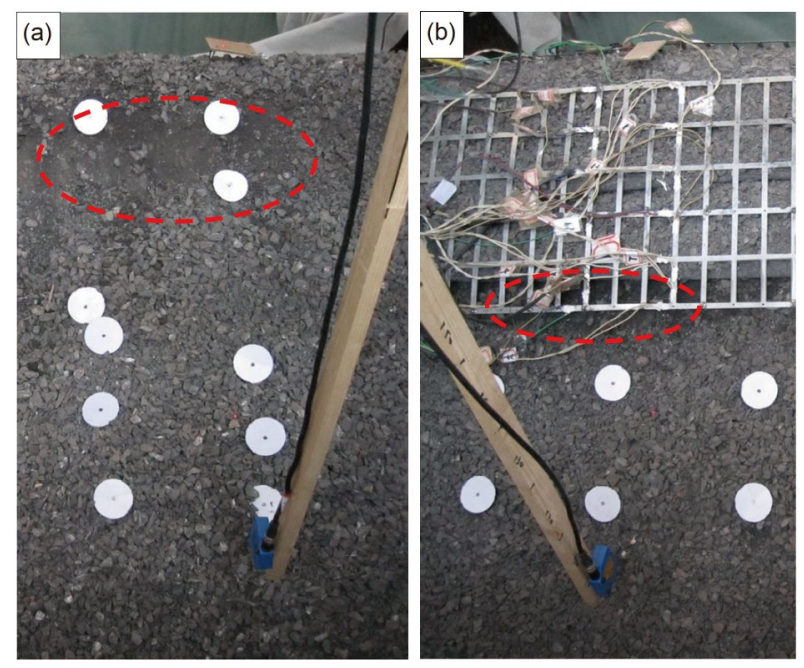

图 11 (网络版彩图)模型坝的破坏形态(工况3). (a) 未加筋; (b) 复合加筋

Figure 11 (Color online) The failure mode of the dam (under the third condition). (a) Without reinforcement; (b) with composite reinforcement.
和阻尼参数, 描述岩土体在动荷载下的滞回曲线和滞 回圈等动力特性 ${ }^{[25,26]}$. 数值计算模型与振动台模型试 验的实际尺寸一致, 共划分 8415 个节点和 5500 个单元, 网格主要采用六面体单元，在坝坡处采用少量五面体 棱柱单元进行过渡. 本构模型采用Mohr-Coulomb动力 弹塑性模型, 筑坝料动剪切模量为 $30 \mathrm{MPa}$, 泊松比为 0.3 , 内摩擦角为 $45^{\circ}$, 阻尼采用Rayleigh阻尼, 阻尼比为 $0.05^{[10]}$. 分别采用Beam单元、Geogrid单元和Shell单元 模拟模型试验中的镀锌铁丝、经编聚酯纤维(PET)和 坝面铁皮网。计算输入的地震波为模型试验振动台台 面实测的加速度时程.

\section{1 数值模拟效果验证}

首先将数值计算结果与试验监测结果进行对比, 限于篇幅, 仅给出工况 2 作用下复合加筋模型坝数值计 算的坝顶坚向位移时程曲线与激光位移计监测结果的 对比, 如图12所示. 由图12可知, 数值计算结果与激光 位移计监测结果的大小和变形规律吻合较好, 说明数 值模拟具有可行性和可靠性.

\section{2 加固机制分析}

高土石坝在地震中出现的坝顶部堆石滑动、沉降 等宏观破坏现象, 都与坝顶产生较大的塑性剪应变有 关 ${ }^{[27]}$, 因此, 分析土石坝坝体塑性剪应变分布对研究 复合加筋抗震措施的加固机制具有重要意义.

图13为蓄水条件, $0.3 g$ 的Taft波作用下，未加筋模 型坝和复合加筋模型坝的坝体剪应变分布. 由图13(a) 可见, 未加筋模型坝的最大剪应变出现在坝顶, 其值

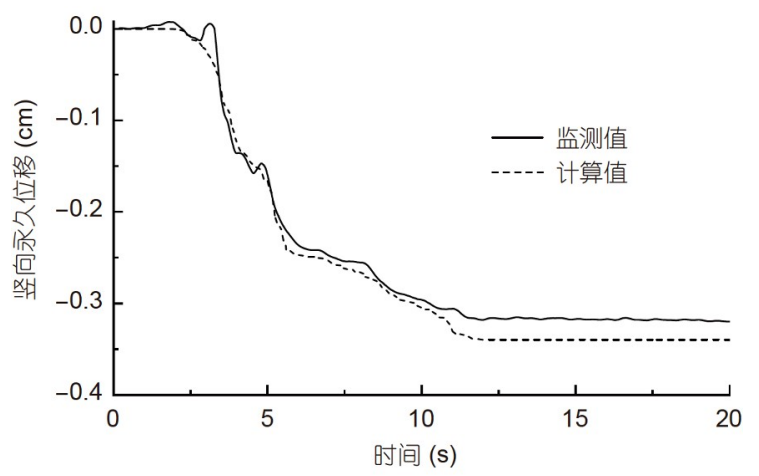

图 12 坝顶坚向位移时程曲线(工况2)

Figure 12 Vertical displacement time history of the dam crest (under the second condition). 
(a)

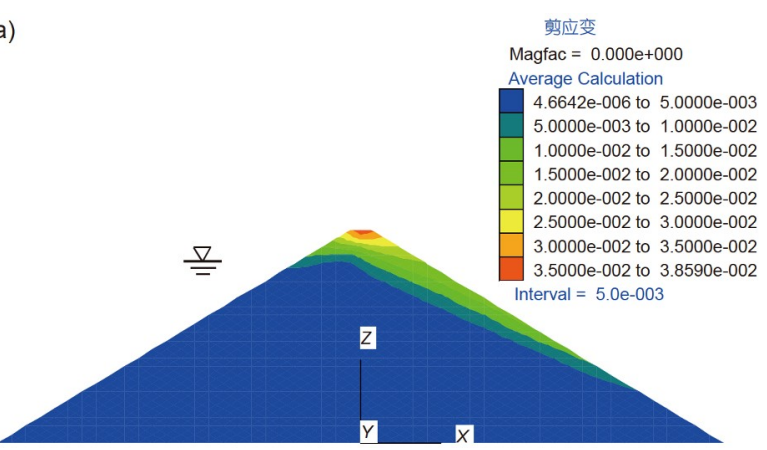

(b)

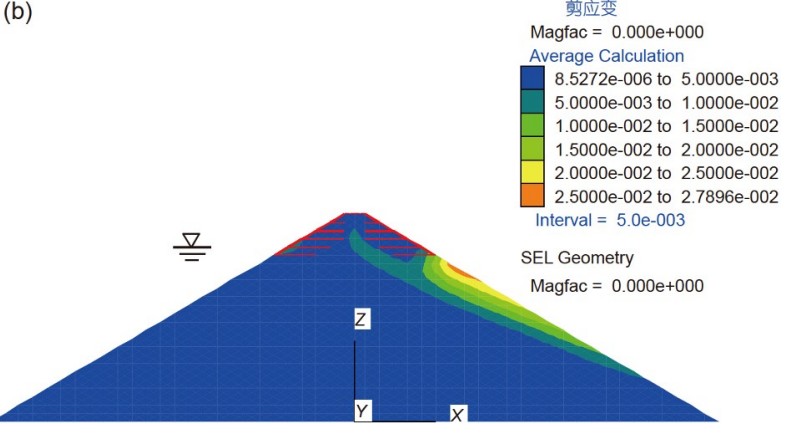

图 13 模型坝坝体剪应变分布. (a) 未加筋; (b) 复合加筋

Figure 13 The distribution of the shear strain of the dam. (a) Without reinforcement; (b) with composite reinforcement.

为 $3.86 \%$, 且同一高程坝坡的剪应变值最大, 并由坝坡 向坝内减小，这也论证了坝顶须进行抗震加固的科学 性和必要性. 上游坝坡由于采用复合土工膜蓄水，水 压力通过复合土工膜抑制了坝坡剪应变的增加. 由图 13(b)可见，采用复合加筋抗震措施后，坝体剪应变分 布规律和幅值较未加筋模型坝发生了显著改变，坝体 最大剪应变的位置下移，出现在复合加筋和未加筋的 坝坡过渡处，其值为 $2.79 \%$ ，这与振动台模型试验中， 在较强振动作用下，少许堆石滚落出现在复合加筋和 未加筋坝坡过渡处的现象相一致. 坝顶复合加筋区域 的剪应变幅值显著降低，较大的剪应变形成在坝内筋 材前端，即坝顶部潜在滑动面由未加筋的浅层滑动转 变为深层滑动, 由于滑动面深度的加深, 因此, 复合加 筋抗震措施提高了坝体抗震稳定性.

为进一步研究复合加筋抗震措施的加固机制, 选 取未加筋模型坝和复合加筋模型坝坝顶部 $(H \geq 80 \mathrm{~cm})$ 下游坝坡两个典型单元 $A$ 和 $B$, 分析地震过程中其剪应 变的变化, 典型单元A和B的位置如图14所示.

图 15 为典型单元 $A$ 和 $B$ 的剪应变时程变化. 由图 15 可以看出, 复合加筋模型坝典型单元 $A$ 和 $B$ 的剪应变值 显著小于未加筋模型坝, 在输入的Taft波的第 $0.5 \sim 1.5 \mathrm{~s}$, 由于该时间段的加速度幅值较大(图5(a)), 未加筋模型 坝和复合加筋模型坝坝坡单元 $A$ 和 $B$ 的剪应变均迅速 增加, 但复合加筋模型坝坝坡单元 $A$ 和 $B$ 在该时间段内 的剪应变水平很低, 且剪应变增加幅值也较未加筋缓 慢. 同时还可以看出, 未加筋模型坝坡面单元A的剪应 变值(地震结束后为 $2.69 \%$ )大于坡内单元 $\mathrm{B}$ 的剪应变值 (地震结束后为 $1.98 \%$ ), 采取复合加筋抗震措施后，坡 面单元A的剪应变值(地震结束后为 $0.07 \%$ )小于坝内单
元B的剪应变值(地震结束后为 $0.1 \%$ ), 即复合加筋抗震 措施起到了“由表及里”的抗震加固效果.

高土石坝在地震中出现的坝顶堆石松动、滚落, 甚至局部浅层滑动等破坏是一个“由表及里”、由浅入 深、逐步发展的过程，复合加筋抗震措施通过坝内筋 材和坝面不锈钢扁钢网的协同作用，将坝顶散粒体堆 石料约束成为了一个整体, 改变了坝顶剪应变幅值和 分布规律，阻止了坝坡滑动的形成，形成了“由表及 里”的抗震加固效果，因此，增强了坝顶堆石的抗震稳

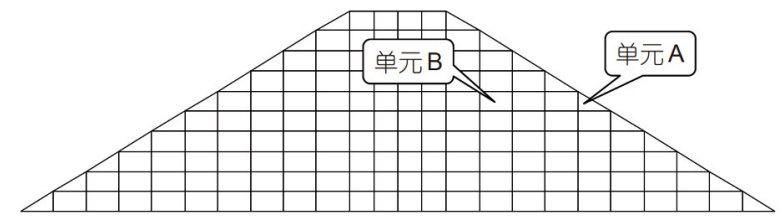

图 14 坝顶典型单元A和B位置 $(H \geq 80 \mathrm{~cm})$

Figure 14 The location of the representative element A and B $(H \geq$ $80 \mathrm{~cm})$.

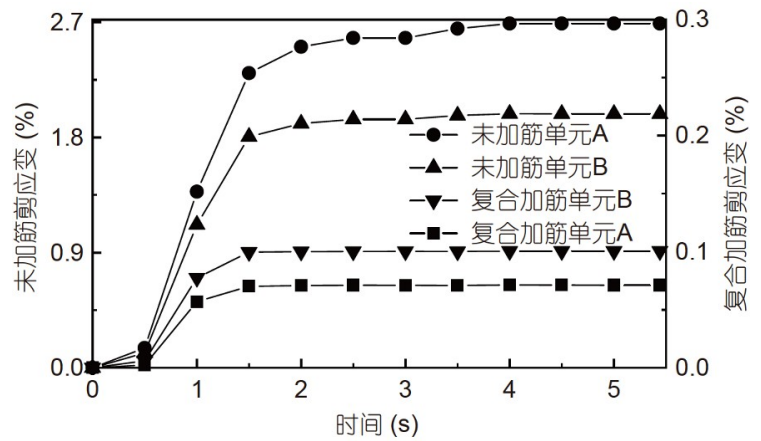

图 15 典型单元 $A$ 和B剪应变时程变化

Figure 15 Shear strain time history of the representative elements A and $\mathrm{B}$. 
定性, 提高了大坝的抗震安全.

鉴于复合加筋与未加筋在坝坡过渡处出现了较大 的剪应变, 振动台模型试验也表明, 在较强振动作用下 该处出现了少许堆石松动、滚落, 甚至脱空现象, 该部 位虽离心墙较远, 对心墙防渗系统影响较小, 但在复合 加筋抗震措施实际实施过程中要做好该部位的衔接, 可采用大块石压重护坡或浆砌石护坡进行过渡.

\section{6 讨论与结论}

通过未加筋模型坝和复合加筋模型坝大型振动台 对比模型试验, 并结合模型试验开展的数值模拟研究, 主要得出以下结论.

(1) 复合加筋抗震措施对坝顶加速度响应具有一 定的抑制作用, 加速度傅里叶谱的幅值也较未加筋小,
复合加筋抗震措施具有减小地震波能量的抗震效果.

(2) 复合加筋抗震措施能减小坝体地震沉降, 对未 加筋模型坝出现的坝顶堆石松动、滚落和浅层滑动等 破坏，起到了有效的抑制作用，具有针对性的抗震 效果.

（3）复合加筋抗震措施通过坝内筋材和坝面不锈 钢扁钢网的协同作用，将坝顶散粒体堆石料约束成为 一个整体, 改变了坝顶剪应变幅值和分布规律, 形成 了“由表及里”的抗震加固效果，增强了大坝的抗震安 全性.

（4）数值计算表明复合加筋与未加筋在坝坡过渡 处出现了较大的剪应变, 振动台模型试验也表明, 在 较强振动作用下该处出现了少许堆石松动、滚落，甚 至脱空现象，在复合加筋抗震措施实际实施中，可在 该部位采用大块石压重护坡或浆砌石护坡进行过渡.

\section{参考文献}

1 Yang X, Liu H L, Yu T, et al. Review on seismic disasters and aseismatic measures of high earth and rockfill dams (in Chinese). J Disaster Prevent Mitigat Eng, 2009, 29: 583-590 [杨星, 刘汉龙, 余挺, 等. 高土石坝震害与抗震措施评述. 防灾减灾工程学报, 2009, 29: 583-590]

2 Wang W S. Seismic Researches for Earth and Rockfill Dams (in Chinese). Beijing: China Electric Power Press, 2013 [汪闻韶. 土石填筑坝抗震 研究. 北京: 中国电力出版社, 2013]

3 Kong X J, Zou D G, Liu J M. Developments in seismic safety evaluation methods and aseismic measures for high rockfill dams (in Chinese). J Hydroel Eng, 2016, 35: 1-14 [孔宪京, 邹德高, 刘京茂. 高土石坝抗震安全评价与抗震措施研究进展. 水力发电学报, 2016, 35: 1-14]

4 Han G C, Kong X J. Aseismatic studies of concrete faced rockfill dams: State-of-the-art (in Chinese). J Dalian Univ Tech, 1996, 36: 708-720 [韩 国城, 孔宪京. 混凝土面板堆石坝抗震研究进展. 大连理工大学学报, 1996, 36: 708-720]

5 Cao X X, He Y L, Chi F D, et al. A new type aseismic reinforcement measures of high earth and rockfill dam using Hardfill (in Chinese). J Hohai Univ (Nat Sci), 2020, 48: 340-346 [曹学兴, 何蕴龙, 迟福东, 等. 高土石坝Hardfill新型抗震加固措施. 河海大学学报(自然科学版), 2020, 48: 340-346]

6 Liu P, Meng M Q, Xiao Y, et al. Dynamic properties of polyurethane foam adhesive-reinforced gravels. Sci China Tech Sci, 2021, 64: 535-547

7 Yang X, Liu H L, Yu T, et al. An aseismic structure of high earth rockfill dam and its construction method (in Chinese). China Patent. ZL 201110122191.5. 2011-11-30 [杨星, 刘汉龙, 余挺, 等. 一种高土石坝抗震结构及其施工方法. 中国专利. ZL 201110122191.5. 2011-11-30]

8 Yang X, Liu H L, Yu T, et al. Technological development of composite reinforcement aseismic measure for high earth rockfill dams and its application (in Chinese). Adv Sci Tech Water Resour, 2016, 36: 69-74 [杨星, 刘汉龙, 余挺, 等. 高土石坝复合加筋抗震加固技术开发与应用. 水利水电科技进展, 2016, 36: 69-74]

9 Kong X J, Zou D G, Deng X J, et al. Comprehensive earthquake resistant measure of high earth-rockfill dams and effectiveness verification (in Chinese). J Hydraul Eng, 2006, 37: 1489-1495 [孔宪京, 邹德高, 邓学晶, 等. 高土石坝综合抗震措施及其效果的验算. 水利学报, 2006, 37: 1489-1495]

10 Yang X, Yu T, Wang X D, et al. Shaking table model tests and numerical simulation of the seismic response behavior of high earth-rockfill dam (in Chinese). J Disaster Prevent Mitigat Eng, 2017, 37: 380-387, 427 [杨星, 余挺, 王晓东, 等. 高土石坝地震响应特性振动台模型试验与数值 模拟. 防灾减灾工程学报, 2017, 37: 380-387, 427]

11 Chen S S, Huo J P, Zhang W M. Analysis of effects of "5.12" Wenchuan Earthquake on Zipingpu concrete face rock-fill dam (in Chinese). Chin J Geotech Eng, 2008, 30: 795-801 [陈生水, 霍家平, 章为民. “5·12”汶川地震对紫坪铺混凝土面板坝的影响及原因分析. 岩土工程学报, 2008, 30: 795-801] 
12 Song S W, Cai D W. Earthquake damage phenomena and deformation monitoring analysis for concrete faced rockfill dam at Zipingpu project during Wenchuan earthquake (in Chinese). Chin J Rock Mech Eng, 2009, 28: 840-849 [宋胜武, 蔡德文. 汶川大地震紫坪铺混凝土面板堆石坝 震害现象与变形监测分析. 岩石力学与工程学报, 2009, 28: 840-849]

13 Yang X, Zhang D, Wu X Y. Seismic design of gravel soil core wall rockfill dam of Changheba hydropower station (in Chinese). Sichuan Water Power, 2016, 35: 25-28 [杨星, 张丹, 伍小玉. 长河坝水电站砾石土心墙堆石坝抗震设计. 四川水力发电, 2016, 35: 25-28]

14 Lei H J, Feng Y L, Liu X N. Research and design of anti-seismic safety of Nuozadu high core wall rock-fill dam (in Chinese). Dam Safety, 2013, 1: 1-4 [雷红军, 冯业林, 刘兴宁. 糯扎渡高心墙堆石坝抗震安全研究与设计. 大坝与安全, 2013, 1: 1-4]

15 Han X J, Zuo X, Chen G X. Development of 98 channels' dynamic signal acquisition system for shaking table test based on virtual instrument technology (in Chinese). J Disaster Prevent Mitigat Eng, 2010, 30: 503-508 [韩晓健, 左喜, 陈国兴. 基于虚拟仪器技术的振动台模型试验98 通道动态信号采集系统研制. 防灾减灾工程学报, 2010, 30: 503-508]

16 Lin G, Zhu T, Lin B. Similarity technique for dynamic structural model test (in Chinese). J Dalian Univ Tech, 2000, 40: 1-8 [林鼻, 朱娅, 林蓓. 结构动力模型试验的相似技巧. 大连理工大学学报, 2000, 40: 1-8]

17 Zhou Y, Lv X L, Lu W S. Shaking table test model design in different structures (in Chinese). Struct Eng, 2006, 22: 37-40 [周颖, 吕西林, 卢文 胜. 不同结构的振动台试验模型等效设计方法. 结构工程师, 2006, 22: 37-40]

18 El-Emam M M, Bathurst R J. Influence of reinforcement parameters on the seismic response of reduced-scale reinforced soil retaining walls. Geotext Geomembr, 2007, 25: 33-49

19 Chen G X, Zhuang H Y, Du X L, et al. A large-scale shaking table test for dynamic soil-metro tunnel interaction: Analysis of test results (in Chinese). J Earthq Eng Eng Vib, 2007, 27: 164-170 [陈国兴, 庄海洋, 杜修力, 等. 土-地铁隧道动力相互作用的大型振动台试验一一试验结 果分析. 地震工程与工程振动, 2007, 27: 164-170]

20 Liu X S, Wang Z N, Wang X G, et al. Large-Scale Shaking Table Model Test and Dynamic Analysis of Concrete Face Dam (in Chinese). Beijing: China Water \& Power Press, 2005 [刘小生, 王钟宁, 汪小刚, 等. 面板坝大型振动台模型试验与动力分析. 北京: 中国水利水电出版社, 2005]

21 Wang N X, Zhang W M, Gu X W, et al. Dynamic centrifuge model test for Changhe dam (in Chinese). Water Power, 2009, 35: 67-70 [王年香, 章 为民, 顾行文, 等. 长河坝动力离心模型试验研究. 水力发电, 2009, 35: 67-70]

22 Kim M K, Lee S H, Choo Y W, et al. Seismic behaviors of earth-core and concrete-faced rock-fill dams by dynamic centrifuge tests. Soil Dyn Earthq Eng, 2011, 31: 1579-1593

23 Yang Z Q, Zhao J M, Liu X S, et al. Large-scale shaking model tests on anti-seismic and reinforcing measures for slope of Zipingpu earth-rock fill dam after “5.12” Wenchuan Earthquake (in Chinese). Chin J Geotech Eng, 2015, 37: 2058-2066 [杨正权, 赵剑明, 刘小生, 等. 紫坪铺大坝下游 坝坡震后抗震加固措施大型振动台模型试验研究. 岩土工程学报, 2015, 37: 2058-2066]

24 Singh R, Roy D. Estimation of earthquake-induced crest settlements of embankments. Am J Eng Appl Sci, 2009, 2: 515-525

25 Itasca Consulting Group, Inc. FLAC ${ }^{3 \mathrm{D}}$ (Fast Lagrangian Analysis of Continua in 3 Dimensions) Version 3.0, User manual. 2004

26 Yang X, Yu T, Yang G. Application of $\mathrm{FLAC}^{3 \mathrm{D}}$ in seismic response analysis of embankment dam (in Chinese). Water Power, 2012, 38: 34-36, 53 [杨星, 余挺, 杨贵. FLAC ${ }^{3 \mathrm{D}}$ 在土石坝地震反应分析中的应用. 水力发电, 2012, 38: 34-36, 53]

27 Zhu Y L, Kong X J, Zou D G, et al. Dynamic response and failure mechanism of high earth-rockfill dams (in Chinese). Chin J Geotech Eng, 2010, 28: 1362-1367 [ 朱亚林, 孔宪京, 邹德高, 等. 高土石坝地震反应和破坏机理分析. 岩土工程学报, 2010, 28: 1362-1367] 


\title{
Large-scale shaking table model tests and numerical simulation for composite reinforcement aseismic measure of high earth rockfill dam
}

\author{
YANG Xing ${ }^{1}$, YU Ting ${ }^{1}$, CHEN Peng ${ }^{2} \&$ YUAN ZhengXin ${ }^{3}$ \\ ${ }^{1}$ Power China Chengdu Engineering Corporation Limited, Chengdu 610072, China; \\ ${ }^{2}$ Dowell Real Estate Development Corporation Limited, Shanghai 201100, China; \\ ${ }^{3}$ Department of Civil and Environmental Engineering, Hong Kong University of Science and Technology, Hong Kong 999077, China
}

The aseismic safety of high earth rockfill dams is an important problem in engineering construction in the intensive earthquake area of West China. A composite reinforcement aseismic measure (CRAM) for high earth rockfill dams was developed. The CRAM's effectiveness and reliability were validated using comparative model tests on a large-scale shaking table. Numerical simulation was used to examine the CRAM's reinforcement mechanism. The results demonstrated that the CRAM had an inhibiting effect on the acceleration response; the CRAM can effectively inhibit the loosening and slipping of rockfill at the crest and reduce earthquakeinduced permanent deformation. The numerical simulation also revealed that the shear strain amplitude and distribution were significantly altered. A slightly larger shear strain appeared at the front of the CRAM's internal reinforcement materials, and the dam slope's potential sliding surface was transformed from shallow sliding to deep sliding. As a result, the CRAM can improve the high earth rockfill dam's seismic safety. The research results can provide a reference for the seismic design of the high rockfill dam in the intensive earthquake area.

high earth rockfill dam, composite reinforcement, aseismic measure, shaking table model test, numerical simulation, reinforcement mechanism

doi: 10.1360/SST-2021-0369 